\title{
The Marketing Stimuli Factors Influencing Consumers' Attitudes to Purchase Organic Food
}

\author{
Song Bee Lian ${ }^{1}$, Meysam Safari ${ }^{2} \&$ Shaheen Mansori ${ }^{3}$ \\ ${ }^{1}$ Faculty of Business, Accounting and Management, SEGi University, Malaysia \\ ${ }^{2}$ Graduate School of Business, SEGi University, Malaysia \\ ${ }^{3}$ Faculty of Business, Communication and Law, INTI International University, Malaysia \\ Correspondence: Song Bee Lian, Faculty of Business, Accounting and Management, SEGi University, No.9, \\ Jalan Teknologi, Taman Sains Selangor, Kota Damansara, PJU5, 47810 Petaling Jaya, Selangor, Malaysia. E-mail: \\ blsong@segi.edu.my
}

Received: May 23, 2016

doi:10.5539/ijbm.v11n10p109

\author{
Accepted: June 1, $2016 \quad$ Online Published: September 20, 2016 \\ URL: http://dx.doi.org/10.5539/ijbm.v11n10p109
}

\begin{abstract}
The demand for organic food products have increased rapidly in recent years. Among the main factors contributed to the increasing global consumers' demand towards organic food products are food safety concern, health benefits, better quality, higher nutritional value and environmental concern. Therefore, there is a need to explore consumers' behaviour towards organic food products. This study attempts to examine the effects of marketing stimuli factors on consumers' attitudes to purchase organic food in Malaysia. Five key marketing stimuli variables were examined in this study, and they were product attributes, price, availability, sales promotion and marketing communications. This study is based on the results of a survey conducted on a sample of 430 organic food consumers in Malaysia. The structural equation modelling was used for data analysis and six hypotheses were tested. The results showed that three marketing stimuli variables of product attributes, availability and sales promotion have significantly influenced consumers' attitudes of organic food. Subsequently, consumers' attitudes is positively correlated to actual purchase of organic food. There was no significant effect of price and marketing communications on consumers' attitudes of organic food. Based on the findings, marketing stimuli strategies should be focused on creating positive attitude of consumers by increasing consumers' awareness, trust, satisfaction and loyalty towards organic food. In addition, price of organic food should be reduced and more effective communication strategies should be undertaken to enhance consumers' purchase of organic food.
\end{abstract}

Keywords: marketing stimuli, consumers' attitude, organic food

\section{Introduction}

In today's era of growing globalism and industrialisation, the world is facing increasing environmental issues. The increased of production and consumption have contributed to serious earth destruction such as air, land and water pollution, biodiversity, climate change, ozone depletion, smog and other natural disasters. Moreover, the growing population imposes problem of sustainability. In the last decades, there has been a progressive increase in environmental consciousness of consumers, and the concern about the environment moved from a fringe to a mainstream issue (Kalafatis, Pollard, East, \& Tsogas, 1999). Ethical consumers have emerged and their main concerns are buying products, which is not harmful to environment and society, as well as strong emphasize on nutritional value, health and quality of food (Wier \& Calverley, 2002). Consumers have become dissatisfied with conventional food products which were produced by adopting intensive agriculture (Gil, Gracia, \& Sanchez, 2000). As a result, the popularity of organic produce increases as it adopted environmental friendly method of production such as free from chemical fertilizers, artificial pesticides, antibiotics, growth hormones, irradiation, food additives, and genetic modification.

Organic food market has become the fastest growing areas of the food market in the United States (U.S), Europe, Australia, and Japan (Makatouni, 2002). Global sales for organic food have reached US\$72 billion and 43.7 million hectares of agricultural land were certified as organic in 2014 (FiBL \& IFOAM, 2015). Similar to many Asian countries, significant transformation is occurring in Malaysia's food and beverage industry as a result of 
globalisation, economic growth, urbanisation, and trade liberalisation In Malaysia, organic food industry is at the developing stage (Organic Alliance Malaysia, 2013). In 2002, Department of Agriculture (DOA) has outlined national standards and the government certification program known as Malaysia Organic Scheme or 'Skim Organik Malaysia' (SOM) with the introduction of standard 'Organic Malaysia' logo. However, Tiraieyari, Hamzah and Samah (2013) found that farmers faced several challenges in adopting organic farming due to expensive certification process, lack of training and technical knowledge to practice organic farming, labour shortages and marketing or supply chain issues. Locally produced organic food products are insufficient to meet the local consumers' demand (Mansori, 2012; Voon, Kwang, \& Agrawal, 2011). Due to the shortage of local supply and increasing demand for organic food products, approximately $70 \%$ of the total organic food products sold in Malaysia are imported from the U.S, Australia, New Zealand, Japan, China, and European countries (Organic Trade Association, 2015).

The high dependence on imported organic food has contributed to high pricing and product quality issues. For example, high price does not match the freshness and superior quality of organic vegetables and fruits (Adman, Squib, \& Abdullah, 2012). Furthermore, Brown (2003) found that consumers faced difficulties in finding organic food products due to lack of information on its availability. In addition, it was observed that lack of sales promotion initiatives undertaken by organic food retailers. All these issues will affect consumers' demand of organic food and growth of organic food industry in Malaysia. Hence, the primary objectives of this exploratory study are; 1) to investigate the effect of product attributes, pricing, availability, sales promotion and marketing communications on consumers' attitude of organic food and 2) to analyse the influence of consumers' attitude towards actual purchase of organic food.

The findings of this research will contribute to managerial and theoretical implications. In the aspect of managerial implications, the research findings will provide valuable information on consumers' attitude to assist in the planning and implementation of marketing strategies by producers or retailers of organic food. In addition, policy makers can develop new policies or subsidy programmes to grow the organic food industry in Malaysia. This investigation will also contribute to theoretical implications in the aspect validation of the Theory of Planned Behaviour (TPB) (Ajzen, 1985).

\section{Literature Review and Hypotheses Development}

\subsection{Theory of Planned Behaviour}

The TPB model has been widely used in the food studies related to consumer behaviour in food decision making, food consumption attitudes and predicting food choices (Chen, 2012). Attitudes refers to individual favourable or unfavourable evaluation of the behaviour in question (Fishbein \& Ajzen, 1975). A person's attitude is influenced by his or her behavioural beliefs and evaluations. Behavioural belief is a person's belief in doing a specific behaviour that will lead to a specific outcome. Additionally, individual's overall evaluation of his or her beliefs will create a desired attitude towards the phenomena (Ajzen, 1991). Behaviour is an individual's observable response in a given situation with respect to a given target (Ajzen, 1991). Ajzen (1991) stated that a behaviour is a function of compatible intentions and perceptions of behavioural control. The TPB underpins the conceptual framework of this study.

This study focused in exploring the attitude-behaviour gap as highlighted in TPB. Aschemann-Witzel and Aagard (2014), Pearson (2014) and Padel and Foster (2005) acknowledged the gap between consumers' attitude and actual purchase behaviour. Pearson (2014) stressed that past literature have limitations in explaining the discrepancy between consumers' generally positive attitude towards organic food and their relatively low levels of purchase.

\subsection{Product Attributes}

Product attributes are classified as intangible and tangible attributes. Intangible attributes describes the non-physical appearance of the organic food product quality, safety, brand and country of origin. As for tangible attributes, it comprises product freshness, taste, labelling and packaging. Several scholars (Edman et al., 2012; Wee, Ariff, Zakuan, Tajudin, Ismail, \& Ishak, 2014; Ahmad \& Juhdi, 2008; Sia, Ooi, Chong, Lim, \& Low, 2013) confirmed that product attributes of organic food have positively influenced consumers' attitude to purchase organic food. In Malaysia, Edman et al. (2012) found that product attributes, such as taste, freshness and packaging, have influenced consumers' attitude to purchase organic food products. According to Wee et al. (2014) and Ahmad and Judhi (2008), product safety of organic food had a significant positive impact on consumers' attitude to purchase organic food. Sia et al. (2013) confirmed that product labelling and certification had a significant relationship with consumers' attitude to purchase organic food. However, poor product attributes of organic certification and logos to create consumers' trust has negatively affected their attitude towards organic 
food (Gerrard, Janssen, Smith, Hamm, \& Padel, 2013). Hence, the following hypothesis will be tested in this respect:

$\mathrm{H}_{1}$ : Product attributes has a positive influence on consumers' attitude of organic food.

\subsection{Price}

Organic food products are generally higher pricing compared to conventional food (Shaharudin, Pani, Mansor, Elias, \& Sadek, 2010). Consumers who prioritised on their long term health benefits are willing to pay more for organic food. Consumers paid higher price for organic food because they perceived healthier and better quality than conventional food, and more environmental friendly (Islam, 2013). Consumers' willingness to pay higher price for organic food due to superior values (Ahmad \& Judhi, 2010; Adman et al., 2012; Voon et al., 2011; Shaharudin et al., 2010).

However, high pricing has caused negative consumers' attitude towards organic food (Sangkumchaliang \& Huang, 2012). Sangkumchaliang and Huang (2012) found that consumers have unclear understanding on organic food labels that created disadvantages in relating product value to the price premium of organic food products, and has negatively affected their attitude to purchase organic food. High price factor with perceived weak contributing value of organic food, have influenced negatively consumers' attitude towards organic food (McEachern \& Willock, 2004). As a result, the following hypothesis is developed:

$\mathrm{H}_{2}$ : Price has significant effect on consumers' attitude of organic food.

\subsection{Availability}

Availability relate to the level of ease or difficulty to purchase a specific product or service. Easy availability of organic food has positively influenced consumers' attitude to purchase organic food (Ahmad \& Judhi, 2008; Hanpermchai \& Dejtanasoontorn, 2011). Consumers could easily access to organic food products due to sufficient supply of organic food at urban areas. In contrast, several scholars (e.g., Mansori, 2012; Voon et al., 2011) have confirmed that limitation in availability of organic food has negatively influenced consumers' attitude to purchase organic food. According to Vermeir and Verbeke (2004), many consumers have positive attitude to purchase organic food, however they unable to purchase the products due to low availability. Therefore, to test this relationship the following hypothesis is formed:

$\mathrm{H}_{3}$ : Availability has a positive influence on consumers' attitude of organic food.

\subsection{Sales Promotion}

According to Gilbert (1999), sales promotional tools such as free sampling and buy-one-get-one-free or in-pack premium item were found to be inducing consumer to purchase more of the product. Chaharsoughi and Yasory (2011) found that sales promotion has positively influenced consumers' attitude to purchase. Teng and Wang (2015) acknowledged that sales promotion was positively correlated to perceived value and purchase intention. However, Noble and Philips (2004) found that customers reject loyalty program memberships due to unattractive sales promotion benefits and perceived negative value, such as loss of social status or loss of freedom in choosing (Wendlandt \& Schrader, 2007). Hence, to explore the relationship between the sales promotion and consumers' attitude towards organic food, the following hypothesis is developed:

$\mathrm{H}_{4}$ : Sales Promotion has a positive influence on consumers' attitude of organic food.

\subsection{Marketing Communications}

According to Belch and Belch (2012), marketing communication campaigns are important in influencing consumers' attitude towards a product. Adequate information communicated to consumers will increase their awareness and knowledge on the benefits of organic food. Effective advertisement through magazine, newspapers and television channels, have enhanced organic food awareness and purchase intention of young female organic food consumers (See \& Mansori, 2012). According to Lim, Yong and Suryadi (2014), word-of-mouth communication was found strongly influenced consumers' attitudes and purchase decisions for organic food as consumers rely on recommendations and advice from their relatives and friends. Leong and Paim (2015) investigated the mediating role of purchase intention on the relationship between media and advertisement, and organic food products consumption among Malaysian Chinese Generation Y consumers. They concluded that purchase intention has a positive effect on the relationship between media and advertisement, and consumption of organic food. However, ineffective marketing communication strategies have created confusion among consumers and negatively affected consumers' attitude to purchase organic food (Henyrks \& Pearson, 2010). Hence, the following hypothesis is formed to examine the relationship between marketing communications and consumer's attitude: 
$\mathrm{H}_{5}$ : Marketing Communications has a positive influence on consumers' attitude of organic food.

\subsection{Consumers' Attitudes}

An attitude is 'a tendency or disposition to respond favourably or unfavourably to an entity'; for example, an event, situation or individual (Eagly \& Chaiken, 1993). Lim et al. (2014) found positive relationship between consumers' intention to purchase attitude and actual purchase of organic food. Consumers with positive attitude towards organic food based on belief and evaluation leads to purchase organic food because it is considered beneficial for them (Suprapto \& Wijaya, 2012). According to Pearson, Henryks and Jones (2010) existed a gap between consumers' generally positive attitude towards organic food and their relatively low level of actual purchases.

\subsection{Actual Purchase}

According to the Model of Consumer Decision Making (Schiffman, 2008) and TPB (Ajzen \& Albarracin, 2007), actual purchase is an important final stage in consumers' process of purchasing a product or service. Consumers' willingness to purchase has a significant direct effect on actual purchase of organic food in Malaysia (Voon et al., 2011). Henryks and Pearson (2010) found that exist a gap of knowledge in the aspect of consumers generally have positive attitude towards organic food, but relatively low level of actual purchases. Pearson (2014) and Aschemann-Witzel and Aagard (2014) reported that higher price and constraint in availability were the causes for consumers' attitude-behaviour gap in organic food industry. There is a lack of attempt from previous organic food studies that have investigated the attitude-behaviour gap (Pearson, 2014). Therefore, to explore the relationship between consumers' attitude and actual purchase, the following hypothesis will be examined:

$\mathrm{H}_{6}$ : Consumers' attitude is directly and positively correlated to the purchase of organic food.

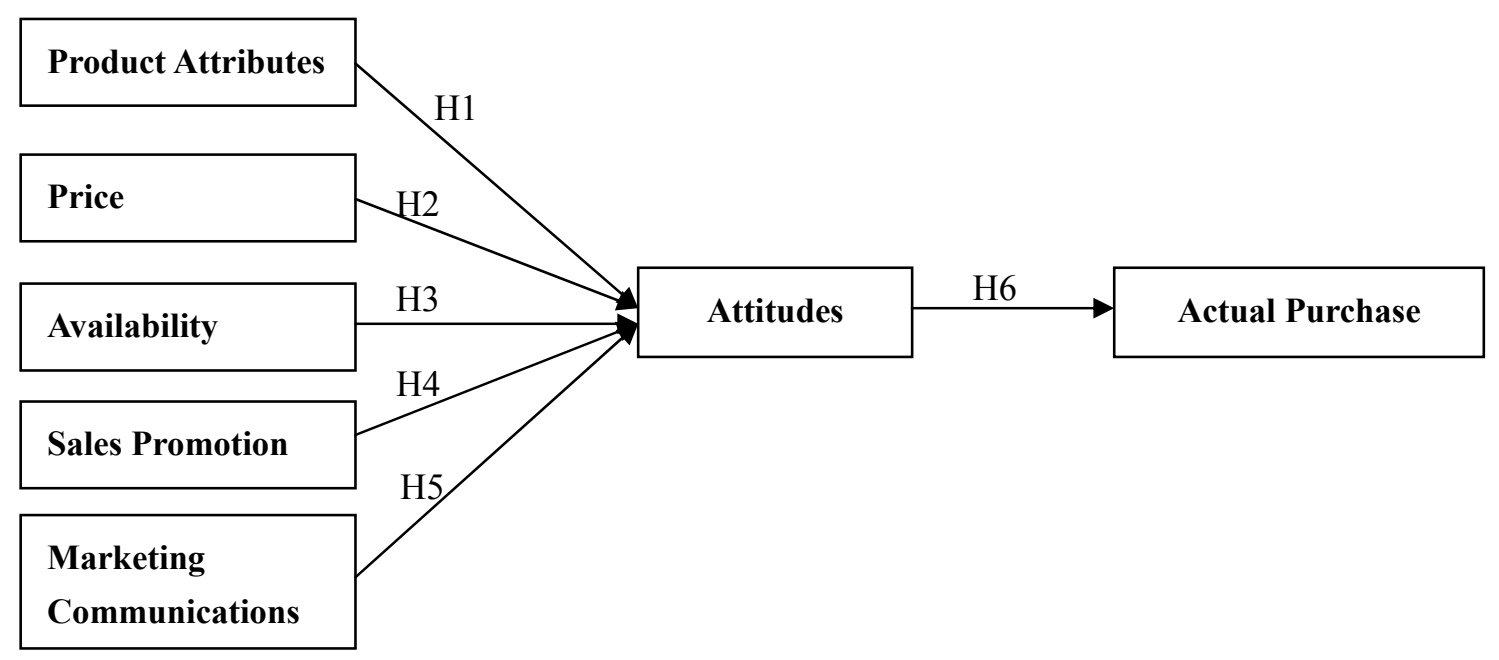

Figure 1. Conceptual framework

\section{Research Methodology}

\subsection{Sampling and Measurement}

The population of this research was individual residing in Malaysia aged 18 and above who is existing consumer of organic food. A total of 18 million populations were estimated in this study (Malaysia Demographics Profile, 2015). Hair, Black, Babin and Anderson (2010) suggested that a minimum sample size of 300 is required for Structural Equation Modeling (SEM) analysis for seven constructs in the structural model. Researcher has determined a sample size of 430 for this study to meet the requirement for SEM analysis and to achieve generalisation of the findings. A total of 430 self-administered questionnaires were distributed in eleven major states of Malaysia (Kuala Lumpur, Selangor, Negeri Sembilan, Johor, Perak, Penang, Kedah, Pahang, Terengganu, Sabah and Sarawak). Non-probability convenience sampling method was used to select the respondents who were consumers present at the selected hypermarkets/supermarkets/specialty retail outlets selling organic food products (Aeon Big, Aeon, Country Farm Organics, BMS Organic, and other stand-alone retail outlets) at the selected states in Malaysia. The survey instrument was designed with 33 items assessed by a six-point Likert scale (1: strongly disagree and 6: strongly agree) and demographic variable with 6 items. The 
scale measured product attributes, price, availability, sales promotion, marketing communications, attitudes and actual purchase. Statistical Package for Social Sciences (SPSS) version 22 was used to perform descriptive analysis, validity and reliability analysis. Subsequently, SPSS AMOS version 21 was used to perform the SEM analysis to test the hypotheses.

\subsection{Validity and Reliability Assessment}

The pilot study comprises the Exploratory Factor Analysis (EFA) to eliminate variables with factor loading $<0.3$ (Hair, Black, Babin, Anderson, \& Tatham, 2006). According to Pallant (2007), the Bartlett's Test of Sphericity value should be significant at $\mathrm{p}<0.05$ and Kaiser-Meyer-Olkin (KMO) value should be 0.6 or above. In examining EFA using Maximum Likelihood extraction and Promax rotation, it has yielded five dimensions (KMO score of 0.693 , Bartlett's Test $\mathrm{p}=0.000(\mathrm{p}<0.05)$. The factor loading for all the 33 proposed items is above 0.3 , however one item of price, i.e. 'Organic food is generally more expensive than conventional food' (item labelled as ' $\mathrm{C} 1$ ') was below 0.3 . Therefore, this one item from price variable was removed from further data analysis. The second round EFA performed on the remaining 33 items and the results confirmed that all the remaining items were accepted with factor loading more than 0.3 with five dimensions extracted. Table 1 shows the results of Confirmatory Factor Analysis (CFA) for each item in the construct.

Table 1 also indicates reliability test results and the Cronbach's Alpha values for all constructs were above 0.7. According to Pallant (2007), the values of 0.7 and above are preferable to demonstrate a high level of internal consistency in the data. The Cronbach's Alpha values were 0.959 (product attributes), 0.933 (Price), 0.844 (Availability), 0.916 (Sales Promotion), 0.894 (Marketing Communications), 0.916 (Attitudes) and 0.882 (Actual Purchase). All dimensions of marketing stimuli factors (product attributes, price, availability, sales promotion and marketing communications), attitudes and actual purchase of organic food were valid and reliable for further inferential analyses.

Table 1. CFA results for the measurement model

\begin{tabular}{|c|c|c|c|c|}
\hline Construct & Item & Statement & $\begin{array}{l}\text { Factor } \\
\text { Loading } \\
\end{array}$ & $\begin{array}{l}\text { Cronbach's } \\
\text { Alpha }\end{array}$ \\
\hline Product & P1 & Organic food tastes better than non-organic food & .812 & .959 \\
\hline \multirow[t]{8}{*}{ Attributes } & $\mathrm{P} 2$ & Organic food are of higher quality & .857 & \\
\hline & P3 & The labels of organic foods are informative & .876 & \\
\hline & P4 & Organic certification logo(s) are clearly stated on the label & .868 & \\
\hline & P5 & $\begin{array}{l}\text { There are new varieties or types of organic food products sold in } \\
\text { retail outlets }\end{array}$ & .877 & \\
\hline & P6 & The product's country of origin (producing country) clearly stated on & .919 & \\
\hline & $\mathrm{P} 7$ & the label of the organic foods & .892 & \\
\hline & P8 & Organic foods are fresher than non-organic foods & .818 & \\
\hline & & $\begin{array}{l}\text { Organic food is safe for consumption as it is free from pesticides, } \\
\text { fertilizers and genetic modifications }\end{array}$ & & \\
\hline \multirow[t]{3}{*}{ Price } & $\mathrm{C} 2$ & I can afford to buy organic foods & .842 & .933 \\
\hline & $\mathrm{C} 3$ & Organic foods have many price levels & .977 & \\
\hline & $\mathrm{C} 4$ & Organic food has a clear price tag & .908 & \\
\hline \multirow[t]{5}{*}{ Availability } & B1 & It is easy to find organic foods in my area & .663 & .844 \\
\hline & B2 & $\begin{array}{l}\text { My preferred organic foods is always sufficiently available at } \\
\text { supermarkets/ specialty stores/open markets }\end{array}$ & .752 & \\
\hline & B3 & $\begin{array}{l}\text { Organic foods are placed at a separate section in the retail outlet that is } \\
\text { easy to find }\end{array}$ & .740 & \\
\hline & B4 & A variety of organic foods is available for selection & .799 & \\
\hline & B5 & Organic foods can be conveniently purchase online & .671 & \\
\hline \multirow[t]{4}{*}{ Sales Promotion } & S1 & Organic foods are discounted occasionally & .785 & .916 \\
\hline & $\mathrm{S} 2$ & My preferred retailer(s) provide free samples of organic food products & .927 & \\
\hline & $\mathrm{S} 3$ & $\begin{array}{l}\text { I receive attractive free premium items from the purchase of organic } \\
\text { foods }\end{array}$ & .919 & \\
\hline & S4 & $\begin{array}{l}\text { Loyalty card that provide privileges to its members are available in } \\
\text { most of the organic food retail outlets }\end{array}$ & .809 & \\
\hline Marketing & M1 & I can easily obtain organic foods information through advertisement & .724 & .894 \\
\hline
\end{tabular}




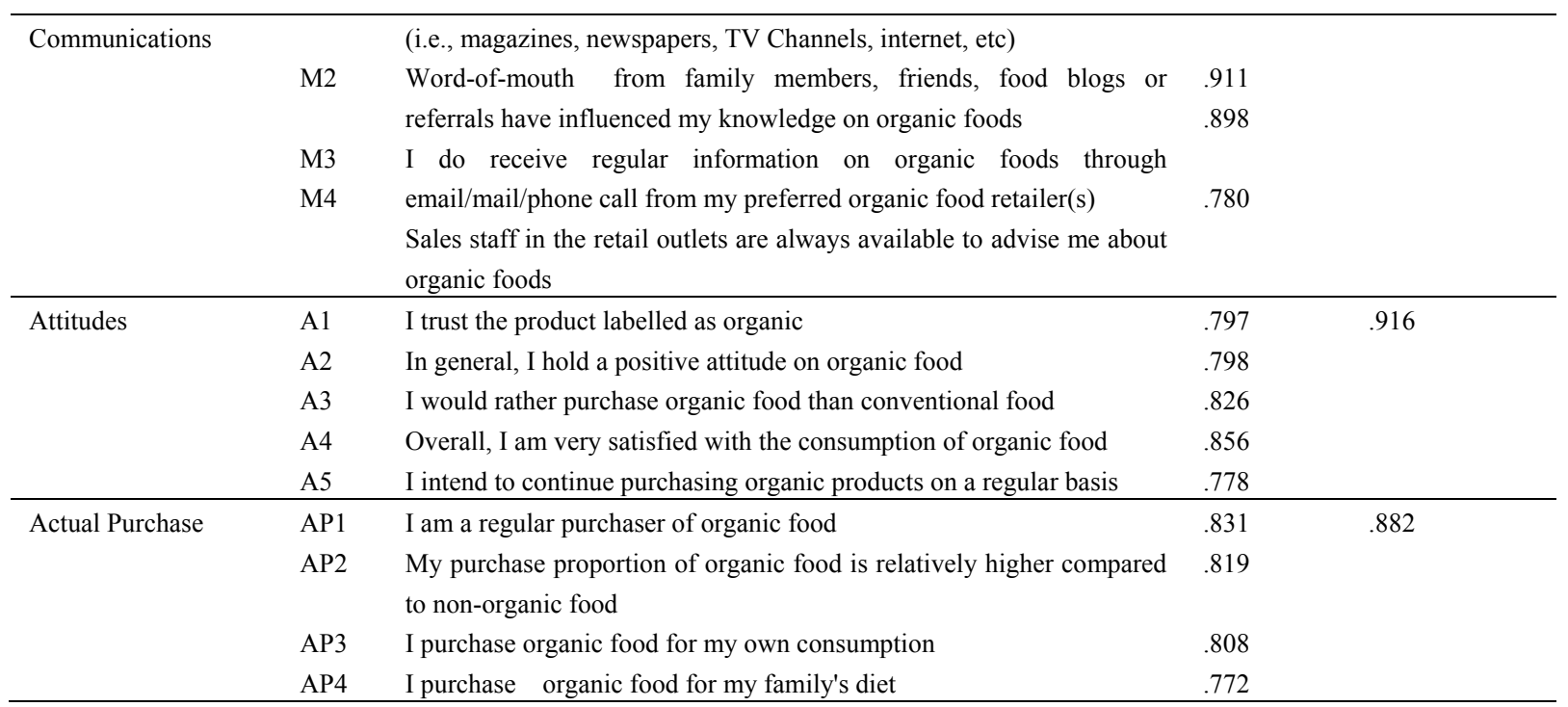

\section{Research Results}

\subsection{Demographic Profile of the Respondents}

The respondents' demographic profile is presented in Table 2. There were 254 female respondents (59\%) and 176 male respondents (41\%) in this study, hence making a total of 430 respondents. Majority respondents of $49.1 \%$ belongs to age category between 39 and 49 . As for the income category, majority respondents of $41.4 \%$ falls between RM3000 and RM6000. The respondents comprises Chinese (51.6\%), Malay (26.3\%), Indian (13.5\%) and others $(8.6 \%)$.

Table 2. Respondents' demographic profile

\begin{tabular}{|c|c|c|}
\hline Demographic Variables & Frequency (n) & Percentage (\%) \\
\hline \multicolumn{3}{|l|}{ Gender } \\
\hline Male & 176 & 41.0 \\
\hline Female & 254 & 59.0 \\
\hline \multicolumn{3}{|l|}{ Age } \\
\hline $18-20$ & 40 & 9.3 \\
\hline $21-38$ & 110 & 25.6 \\
\hline $39-49$ & 211 & 49.1 \\
\hline$\geq 50$ & 69 & 16.0 \\
\hline \multicolumn{3}{|l|}{ Income } \\
\hline$<\mathrm{RM} 1500$ & 20 & 4.7 \\
\hline RM1500- RM3000 & 57 & 13.3 \\
\hline RM3000-RM6000 & 178 & 41.4 \\
\hline RM6000-RM10000 & 135 & 31.4 \\
\hline$>$ RM10000 & 40 & 9.2 \\
\hline \multicolumn{3}{|l|}{ Race } \\
\hline Chinese & 222 & 51.6 \\
\hline Malay & 113 & 26.3 \\
\hline Indian & 58 & 13.5 \\
\hline Others & 37 & 8.6 \\
\hline \multicolumn{3}{|l|}{ State } \\
\hline Selangor & 39 & 9.2 \\
\hline Kuala Lumpur & 40 & 9.3 \\
\hline Penang & 40 & 9.3 \\
\hline Kedah & 37 & 8.6 \\
\hline Pahang & 39 & 9.1 \\
\hline Perak & 38 & 8.8 \\
\hline Negeri Sembilan & 40 & 9.3 \\
\hline Johor & 41 & 9.5 \\
\hline Terengganu & 41 & 9.5 \\
\hline Sabah & 38 & 8.8 \\
\hline Sarawak & 37 & 8.6 \\
\hline
\end{tabular}




\subsection{Model Compatibility Testing}

SEM was used to measure the proposed research model and hypotheses. Table 3 shows the results of model compatibility testing using chi-square, Chisq/df, RMSEA, IFI, CFI and TLI.

Table 3. Goodness of fit

\begin{tabular}{llll}
\hline Index & Level of Acceptance & Result & Model Evaluation \\
\hline Chi-square & $\mathrm{P}>0.05$ & 1413.071 & Good \\
Chisq/df & Chi Square $/ \mathrm{df}<3.0$ & 2.765 & Good \\
RMSEA & RMSEA $<0.08$ & 0.064 & Good \\
IFI & IFI $>0.9$ & 0.921 & Good \\
CFI & CFI $>0.9$ & 0.921 & Good \\
TLI & TLI $>0.9$ & 0.913 & Good \\
\hline
\end{tabular}

Overall, the research model has achieved a good fit. The chi-Square value was 1413.071 and according to Barrett (2007), chi square probability value greater than 0.05 indicates acceptable model fit. The ratio of $x^{2} / \mathrm{df}$ was 2.765 , lower than the value 3.0, as suggested by Byrne (2001) and Marsh and Hocevar (1985). Incremental fit values were greater than 0.9 , with IFI of 0.921 , CFI of 0.921 and TLI of 0.913 . As for the absolute index, RMSEA of 0.064 which was lower than 0.8, as suggested by Browne and Cudeck (1993). After the fitness indices have been achieved, the normality assessment was examined to assess the distribution for every variable in the dataset before proceeding to modelling the structural model. By using SEM with Maximum Likelihood Estimator, the results shown the data is normally distributed with value of skewness between -1.0 and 1.0, and kurtosis of between -3.0 and 3.0. Subsequently, estimated path coefficients were derived for the examined relationships and the research hypotheses were examined.

\subsection{Model Causality Testing}

The regression weights and probability value which indicates its significance is shown in Table 4 and final structural model is shown in Figure 2. Based on the results, product attributes had direct positive effect $(0.207)$ on attitudes and shown significant $\mathrm{P}$ value. Therefore, $\mathrm{H}_{1}$ which proposed product attributes has a positive influence on consumers' attitudes of organic food is accepted. The regression coefficient of the relationship between price and consumers' attitudes is not significant (0.076). As a result, $\mathrm{H}_{2}$ which proposed price has significant effect on consumers' attitudes of organic food is rejected. Subsequently, availability had direct positive effect (0.594) on consumers' attitudes and shown significant $\mathrm{P}$ value. Therefore, $\mathrm{H}_{3}$ which proposed availability has a positive influence on consumers' attitudes of organic food is accepted. The regression coefficient of the relationship between sales promotion and attitudes is significant (0.165). As a result, $\mathrm{H}_{4}$ which proposed sales promotion has a positive influence on consumers' attitudes of organic food.is accepted. It has shown the regression coefficient of the relationship between marketing communications and consumers' attitudes is not significant (0.049). Therefore, $\mathrm{H}_{5}$ which proposed marketing communications has a positive influence on consumers' attitudes of organic food is rejected. Lastly, consumers' attitudes had direct positive effect $(0.426)$ on actual purchase of organic food and shown significant $\mathrm{P}$ value. It was concluded that $\mathrm{H}_{6}$ which proposed consumers' attitudes is directly and positively correlated to actual purchase of organic food is accepted.

Table 4. Regression weights and the probability value which indicates its significance

\begin{tabular}{|c|c|c|c|c|c|c|c|}
\hline Paths & & & Estimate & S.E. & C.R. & $\mathbf{P}$ & Result \\
\hline Attitudes & $<---$ & Product Attributes & .207 & .040 & 5.153 & .001 & Supported \\
\hline Attitudes & $<---$ & Price & .076 & .054 & 1.413 & .158 & Rejected \\
\hline Attitudes & $<---$ & Availability & .594 & .080 & 7.384 & .001 & Supported \\
\hline Attitudes & $<---$ & Sales Promotion & .165 & .056 & 2.945 & .003 & Supported \\
\hline Attitudes & $<---$ & Marketing Communications & .049 & .059 & 0.832 & .405 & Rejected \\
\hline Actual Purchase & $<---$ & Attitude & .426 & .039 & 10.904 & .001 & Supported \\
\hline
\end{tabular}




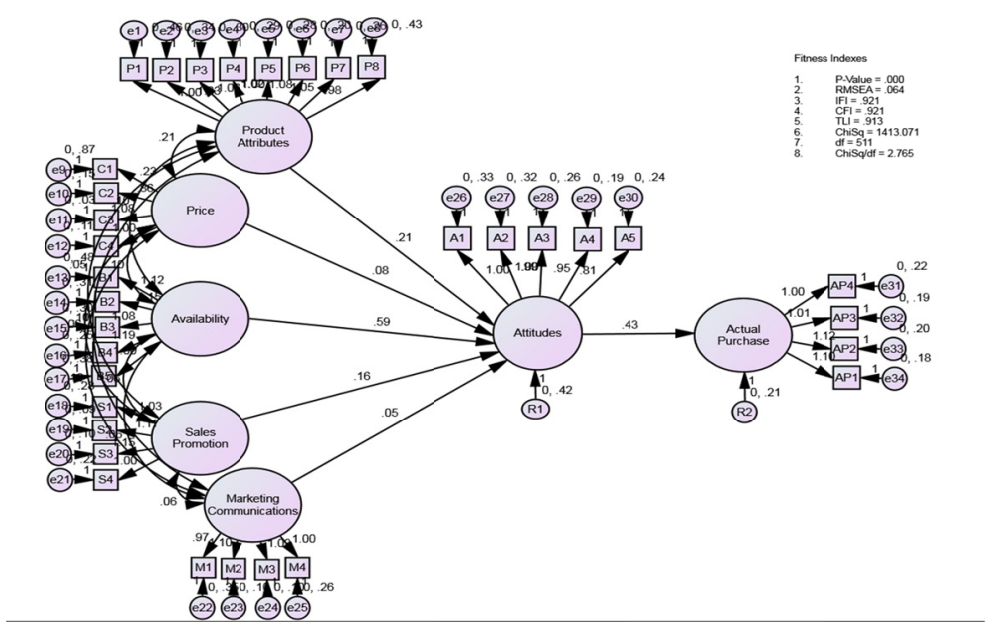

Figure 2. Final structural model

\section{Discussion}

The results of this research shown that product attributes, availability, sales promotion and attitudes are main important factors that influenced consumers' actual purchase of organic food in Malaysia. The present study validated a model that predicts consumers' attitudes and actual purchase of organic food among Malaysian consumers which are consistent with the TPB model. Although product attributes of organic food is positively related to attitudes, the correlation coefficient value still considered as weak according to 'Guilford Rule of Thumb', with $\mathrm{r}$ value of below 0.4 (Guilford, 1956). The results have supported the previous studies by Edman et al. (2012); Wee et al. (2014); Ahmad and Juhdi (2008); Sia et al. (2013). Hence, marketers should focus on improving the taste, quality, labelling information and freshness of organic food products. Clear and detailed product labelling comprising country of origin, nutritional value and organic certification logos are important to increase consumers' trust on organic food. Moreover, organic food manufacturers should emphasize on innovativeness of organic food produce to provide more diverse choice to consumers and improve their satisfaction level. For example, local manufacturers should collaborate with other manufacturers from overseas to acquire new techniques and skills of producing high quality organic food. Additionally, the Government should take initiatives to promote awareness of organic food to the public by emphasizing on important product attributes, such as better quality, safe for consumption and organic certification process to increase consumers' trust on organic food products.

The result of this research also confirmed that price has no significant effect on consumers' attitudes of organic food. Price of organic food should be reduced to increase consumers' demand, particularly to encourage purchase from more middle to high income consumers. Policymakers should take initiatives to encourage local organic farmers by providing subsidies and financial assistance to reduce the dependence on imported organic food products which have contributed to the high pricing due to imported tax. In addition, sensitivity towards the pricing affected consumers' attitudes to purchase. Availability has recorded the highest correlation coefficient value with consumers' attitudes. Hence, this indicated that Malaysian consumers' agreed availability of organic food is not an issue in most of the places in Malaysia. The results have supported the previous study by Ahmad and Judhi (2008). Organic food retailers should make availability easier via online purchase for the convenience of consumers. This would help to reduce the cost of selling the products and contribute to price reduction.

Sales promotion also has significant effect on consumers' attitudes. The results obtained are consistent with the findings from previous studies by Chaharsoughi and Yasory (2011) and Teng and Wang (2015). Attractive sales promotional activities, such as discounts on packaged items, loyalty card programme, free premium items and free sampling, should be carried out more intensively to induce consumers to purchase organic food. Consumers would often relate the sales promotion obtained with the price and determine whether good value received from the purchase of organic food. Marketing communications has no significant influenced on consumers' attitudes of organic food. The results obtained are consistent with the previous study by Henyrks and Pearson (2010). Public education campaign on organic food awareness should be jointly organised by the Government and retailers. More aggressive advertising, word of mouth and direct marketing should be prioritised by the retailers. 
In this study, consumers' attitudes have a strong positive relationship with actual purchase. This implies that consumers' awareness, trust, satisfaction and loyalty were important influencing factors in their purchase of organic food. The results are consistent with earlier studies by Lim et al. (2014) and Suprapto and Wijaya (2012). It also proven that these attitudes serve as important drivers for consumers' purchase and consumption of organic food in Malaysia. Therefore, it is important for marketers of organic food products to produce organic food, set pricing, ensure easy availability of organic food and design their marketing communications and sales promotion activities based on these objectives to encourage more purchase of organic food products by consumers.

\section{Conclusion, Limitations and Recommendations}

From the current study, it can be concluded that three marketing stimuli variables of product attributes, availability and sales promotion have significantly influenced consumers' attitudes of organic food. Additionally, consumers' attitudes is positively correlated to the actual purchase of organic food. In contrast, price and marketing communications have no significant effect on consumers' attitudes of organic food.

As for the limitation of this study, the investigation of consumers' purchase organic food is only observed through the influence of five key marketing stimuli factors and consumers' attitudes of organic food. Future studies should explore on other important influencing factors such as consumers' knowledge and awareness of organic food, lifestyle, demographic and cultural factors.

\section{References}

Ahmad, S. N. B., \& Juhdi, N. (2008). Consumer's perceptions and purchase intentions toward organic food products: An explorative study on attitudes of Malaysian consumers. 16th Annual Conference on pacific basin Finance, Economics, Accounting and management, Brisbane, Australia.

Ahmad, S. N. B., \& Judhi, N. (2010). Organic Food: A Study on Demographic Characteristics and Factors Influencing Purchase Intentions among Consumers in Klang Valley, Malaysia. International Journal of Business and Management, 5(2), 105-118. http://dx.doi.org/10.5539/ijbm.v5n2p105

Ajzen, I. (1985). From intentions to actions: A theory of planned behavior. In J. Kuhl \& J. Beckmann (Eds.), Action Control: From Commitment to Behaviour. Heidelberg: Springer.

Ajzen, I. (1991). The theory of planned behavior. Organizational Behavior and Human Decision Processes, 50(2), 179-211.

Ajzen, I., \& Albarracin, D. (2007). Predicting and changing behavior: a reasoned action approach. In I Ajzen, D. Albarracín, \& R. Hornik (Eds.), Prediction and change of health behavior: Applying the reasoned action approach, Lawrence Erlbaum. Associates, Mahwah, NJ.

Aschemann-Witzel, J., \& Aagaard, N. (2014). Elaborating on the attitude-behaviour gap regarding organic products: Young Daish consumers and in-store food choice. International Journal of Consumer Studies, 38(5), 550-558. http://dx.doi.org/10.1111/ijcs.12115

Barrett, P. (2007). Structural Equation Modelling: Adjudging Model Fit. Personality and Individual Differences, 42(5), 815-24. http://dx.doi.org/10.1016/j.paid.2006.09.018

Belch, G., \& Belch, A. (2012). Advertising and Promotion: An Integrated Marketing Communications Perspective. McGraw-Hill.

Brown, C. (2003). Consumers' preferences for locally produced food: A study in Southeast Missouri. American Journal of Alternative Agriculture, 18(4), 213-224. http://dx.doi.org/10.1079/AJAA200353

Browne, M. W., \& Cudeck, R. (1993). Alternative ways of assessing model fit. In K. A. Bollen \& J. S. Long (Eds.), Testing structural equation models (pp. 136-162). Beverly Hills, CA: Sage.

Byrne, B. M. (2001). Structural equation modeling with AMOS: Basic concepts, applications and programming. Mahwah, N.J.: Lawrence Erlbaum Associates.

Chaharsoughi, S. A., \& Yasory, T. H. (2011). Effect of sales promotion on consumer behavior based on culture. African Journal of Business Management, 6(1), 98-102. http://dx.doi.org/10.5897/AJBM11.739

Chen, J. (2012). A study investigating the determinants of consumer buying behaviour relating to the purchase of organic food products in urban China. Retrieved on 10 December 2015 from http://researchbank.swinburne.edu.au/vital/access/manager/Repository/swin:29130

Department of Statistic Malaysia. (2014). Total Populations. Retrieved on $3^{\text {rd }}$ March, 2015 from http://statistics.gov.my 
Eagly, A. H., \& Chaiken, S. (1993). The psychology of attitudes. Fort Worth, TX: Harcourt Brace Jovanovich College Publishers.

Edman, S., Squib, A., \& Abdullah, A. (2012). Study on Demographic Characteristics and Exploring the Attitude among Consumers on Organic Jungle Foods in Kuching, Sarawak. Retrieved on 10th March 2016 from http://www.feb.unimas.my/index.../4_7c900860fc8b641c7bada41f5ccd3819

FiBL, \& IFOAM. (2015). Organic Agriculture Worldwide: Current Statistics. Retrieved on Feb 24, 2016 from http://orgprints.org/28216/7/willer-lernoud-2015-02-11-global-data.pdf

Fishbein, M., \& Ajzen, I. (1975). Belief, attitude, intention, and behavior: An introduction to theory and research. Reading, MA: Addison-Wesley.

Gerrard, C., Janssen, M., Smith, L., Hamm, U., \& Padel, S. (2013). UK consumer reactions to organic certification logos. British Food Journal, 115(5), 727-742. http://dx.doi.org/10.1108/00070701311331517

Gil, J. M., Gracia, A., \& Sanchez, M. (2000). Market Segmentation and Willingness to Pay for Organic Products in Spain. The International Food and Agribusiness Management Review, 3(2), 207-226. http://dx.doi.org/10.1016/S1096-7508(01)00040-4

Gilbert, D. (1999). Retail Marketing Management. Harlow: Prentice Hall.

Guilford, J. P. (1956). Fundamental Statistics in Psychology and Education. New York: McGraw Hill.

Hair, J. F. J., Black, W. C., Babin, B. J., Anderson, R. E., \& Tatham, R. L. (2006). Multivariate Data Analysis (6th ed.). Upper Saddle River, NJ: Pearson Prentice Hall.

Hanpermchai, P., \& Dejtanasoontorn, S. (2011). Purchasing Organic Foods Online Controversial Issue in Marketing. Retrieved on 20th April 2016 from http://www.divaportal.se/smash/get/diva

Henryks, J., \& Pearson, D. (2010). Marketing communications create confusion: Perception versus reality for Australian organic food consumers. Australian and New Zealand Communications Association Conference: Media Democracy and Change, 7-9 July, Canberra, Australia.

Islam, S. (2013). Retail Price Differential between Organic and Conventional Foods. ASBBS Annual Conference: Las Vegas, 20(1), 537-545.

Kalafatis, S., Pollard, M., East, R., \& Tsogas, M. (1999). Green Marketing and Ajzen's Theory of Planned Behaviour: A Cross-market Examination. Journal of Consumer Marketing, 16(5), 441-460. http://dx.doi.org/10.1108/07363769910289550

Leong, P. L., \& Paim, L. (2015). Mediating Effects of Intention on the Factors Affecting Organic Food Products Consumption among Chinese Generation Y in Malaysia. International Journal of Business Research and Management, 6(1), 1-19.

Lim, W. M., Yong, L. S., \& Suryadi, K. (2014). Consumers' Perceived Value and Willingness to Purchase Organic Food. Journal of Global Marketing, 27, 298-307. http://dx.doi.org/10.1080/08911762.2014.931501

Makatouni, A. (2002). What motivates consumers to buy organic food in the UK? Results from a qualitative study. British Food Journal, 104(3-5), 345-52.

Malaysia Demographics Profile. (2015). Retrieved on November 1, 2015 from http://www.indexmundi.com/malaysia/demographics_profile.html

Marsh, H. W., \& Hocevar, D. (1985). Application of confirmatory factor analysis to the study of self-concept: First- and higher-order factor models and their invariance across groups. Psychological Bulletin, 97(3), 562-582. http://dx.doi.org/10.1037/0033-2909.97.3.562

McEachern, M. G., \& Willock, J. (2004). Producers and consumers of organic meat: A focus on attitudes and motivations. British Food Journal, 106, 534-552. http://dx.doi.org/10.1108/00070700410545737

Organic Trade Association. (2013). The South-East Asian Market for Organic food and Drink. Retrieved on $5^{\text {th }}$ April, 2016 from http://www.ota.com/pics/documents/SEAsia.pdf

Padel, S., \& Foster, C. (2005). Exploring the gaps between attitudes and behaviour: Understanding Why Consumers Buy or Do Not Buy Organic Food. British Food Journal, 107(8), 606-625. http://dx.doi.org/10.1108/00070700510611002

Pallant, J. (2007). SPSS survival manual: A step by step guide to data analysis using SPSS for Windows (Version 15) (3rd ed.). Allen \& Unwin, Sydney. 
Pearson, D. (2014). Strengthening the bridge between consumers and their organic food choices. Proceedings of the 4th ISOFAR Scientific Conference. 'Building Organic Bridges', at the Organic World Congress 2014, 13-15 Oct., Istanbul, Turkey.

Pearson, D., Henryks, J., \& Jones, H. (2010). Misreading between the lines:Consumer confusion over organic food labelling. Australian Journal of Communication, 37(3), 73-86.

Sangkumchaliang, P., \& Huang, W. (2012). Consumers' Perceptions and Attitudes of Organic Food Products in Northern Thailand. International Food and Agribusiness Management Review, 15(1), 87-102.

Schiffman, L. G. (2008). Consumer Behaviour. Pearson Education Limited, US.

See, S. Z., \& Mansori, S. (2012). Young Female Motivations for Purchase of Organic Food in Malaysia. International Journal of Contemporary Business Studies, 3(5), 61-72.

Shaharudin, M., Pani, J., Mansor, S., Elias, S., \& Sadek, R. (2010). Purchase Intention of Organic Food in Malaysia; A Religious Overview. International Journal of Marketing Studies, 2(1). http://dx.doi.org/10.5539/ijms.v2n1p96

Sia, B. K., Ooi, B. C., Chong, S. C., Lim, C. S., \& Low, L. T. (2013). Determinants of Willingness to Pay of Organic Products. Middle-East Journal of Scientific Research, 14(9), 1171-1179. http://dx.doi.org/10.5829/idosi.mejsr.2013.14.9.1959

Suprapto, B., \& Wijaya, T. (2012). Intentions of Indonesian Consumers on Buying Organic Food. International Journal of Trade, Economics and Finance, 3(2), 114-119. http://dx.doi.org/10.7763/IJTEF.2012.V3.183

Teng, C. C., \& Wang, Y. M. (2015). Decisional factors driving organic food consumption: Generation of consumer purchase intentions. British Food Journal, 117(3), 1066-1081. http://dx.doi.org/10.1108/BFJ-12-2013-0361

Tiraieyari, N., Hamzah, A., \& Samah, B. A. (2013). Organic Farming and Sustainable Agriculture in Malaysia: Organic Farmers' Challenges towards Adoption. Asian Social Science, 10(4), 289-294. http://dx.doi.org/10.5539/ass.v10n4p1

Vermeir, I., \& Verbeke, W. (2006). Sustainable Food Consumption: Exploring the Consumer Attitude-Behavior Gap. Journal of Agricultural and Environmental Ethics, 19(2), 169-194. http://dx.doi.org/10.1007/s10806-005-5485-3

Voon, J. P., Kwang, S. N., \& Agrawal, A. (2011). Determinants of Willingness to Purchase Organic Food: An Exploratory Study Using Structural Equation Modeling. International Food and Agribusiness Management Review, 14(2), 103-120.

Wee, C. S., Ariff, M. S. B. M., Zakuan, N., Tajudin, M. N. M., Ismail, K., \& Ishak, N. (2014). Consumers' perception, purchase intention and actual purhcase behaviour of organic food products. Review of Integrative Business and Economics Research, 3(2), 378.

Wendlandt, M., \& Schrader, U. (2007). Consumer reactance against loyalty programs. Journal of Consumer Marketing, 24(5), 293-304. http://dx.doi.org/10.1108/07363760710773111

Wier, M., \& Calverley, C. (2002). Market Perspectives for Organic Foods in Europe. British Food Journal, 104(1), 45-62.

\section{Copyrights}

Copyright for this article is retained by the author(s), with first publication rights granted to the journal.

This is an open-access article distributed under the terms and conditions of the Creative Commons Attribution license (http://creativecommons.org/licenses/by/4.0/). 